\title{
Comparative effects of anti-inflammatory corticosteroids in human bone-derived osteoblast-like cells
}

\author{
H. Namkung-Matthäi*, J.P. Seale**, K. Brown***, R.S. Mason*
}

Comparative effects of anti-inflammatory corticosteroids in human bone-derived osteoblast- like cells. H. Namkung-Matthäi, J.P. Seale, K. Brown, R.S. Mason. @ERS Journals Ltd 1998.

ABSTRACT: While effects of inhaled corticosteroids on serum markers of bone metabolism in normal and asthmatic subjects have been reported, there are little data on the direct effects of these corticosteroids on end-organs such as bone. The results presented here compare the effects of budesonide and its epimers (22S- and 22Rbudesonide), fluticasone and dexamethasone on growth and differentiation of cultured human bone cells.

Osteoblast-like cells were cultured from human foetal bone chips grown to confluence and used at first subculture.

At concentrations of 10.11-10-7 $\mathrm{M}$ each corticosteroid (CS) caused a dose-dependent decrease in $\left.{ }^{[} \mathrm{H}\right]$ thymidine incorporation into deoxyribonucleic acid (DNA), median effective concentration (EC50): fluticasone $(0.06 \mathrm{nM})>22 \mathrm{R}(0.26 \mathrm{nM})>22 \mathrm{~S}(0.4 \mathrm{nM})$ $>$ budesonide $(0.47 \mathrm{nM})>$ dexamethasone $(1.5 \mathrm{nM})$. Each $\mathrm{CS}$ resulted in a dose-dependent increase in alkaline phosphatase activity, EC50: fluticasone $(0.14 \mathrm{nM})>22 \mathrm{R}(0.2$ $\mathrm{nM})=22 \mathrm{~S}(0.2 \mathrm{nM})>$ budesonide $(0.4 \mathrm{nM})>$ dexamethasone $(1.6 \mathrm{nM})$. The 1,25 dihydroxyvitamin $\mathrm{D}_{3}\left(1,25(\mathrm{OH})_{2} \mathrm{D}_{3}\right)$-stimulated osteocalcin production was decreased in the presence of each CS, EC50: fluticasone $(0.02 \mathrm{nM})>22 \mathrm{~S}(0.1 \mathrm{nM})>22 \mathrm{R}(0.2 \mathrm{nM})$ $>$ budesonide (1.0 nM) >dexamethasone $(1.8 \mathrm{nM})$.

In human bone cells the potencies of fluticasone and budesonide in relation to dexamethasone are not dissimilar to those derived from human lymphocytes in vitro. Eur Respir J 1998; 12: 1327-1333.
Depts of *Physiology and Institute for Biomedical Research, $* *$ Pharmacology and ***Pharmacy, University of Sydney, Australia.

Correspondence: R.S. Mason

Dept of Physiology and Institute for Biomedical Research

University of Sydney

NSW 2006

Australia

Fax: 61293512058

Keywords: Alkaline phosphatase bioactivity

bone-derived cells

corticosteroids

osteocalcin

proliferation

Received: December 291997

Accepted after revision August 91998
Inhaled anti-inflammatory corticosteroids are now widely used in the management of asthma and other types of obstructive airway disease. At higher doses there is systemic absorption, but the biochemical and clinical effects of this absorption (either short- or long-term) have not been fully assessed. For the last decade there has been a tendency to use inhaled corticosteroids at high dosages (e.g. $>2,000 \mu \mathrm{g}$ ) for patients with severe asthma, but there is now some concern that systemic effects, such as posterior subcapsular cataracts, may manifest themselves after patients have used these higher doses for several years [1, 2]. Bruising or thinning of the skin is now recognized as a phenomenon associated with high-doses of inhaled corticosteroids [3] and more recent studies have investigated the effects of inhaled corticosteroids on indirect indices of bone metabolism such as serum osteocalcin [4] and procollagen concentrations [5].

It has been assumed that the relative potencies of different corticosteroids are constant for all biological effects. Thus, if the ratio for anti-inflammatory activity for two corticosteroids is $3: 1$ then it is presumed that the same ratio will also pertain to the unwanted systemic effects on bone, skin and glucose metabolism.

There are several ways in which differences between the various inhaled corticosteroids could modify the ratio of systemic effects of inhaled corticosteroids. These include different rates of absorption across the lung epithelium, metabolic degradation and differences in end-organ sensitivity. Deposition within the lung and subsequent systemic absorption will depend on particle size and the consequent site of deposition within the respiratory tree. Smaller particle size will be associated with more peripheral distribution in the lung and with a greater likelihood of systemic absorption. Physicochemical characteristics of the drug will also be relevant. Recent evidence has suggested that transpulmonary administration of these drugs via the inhaled route is a significant source of detectable plasma corticosteroid [6].

The relative sensitivity of target organs such as bone and skin to unwanted effects of inhaled corticosteroids may also modify the systemic effects of inhaled corticosteroids. Long-term systemic administration of corticosteroids, such as prednisolone, results in osteoporosis and several studies have indicated that osteoporosis may result from treatment with higher doses of inhaled corticosteroids $[7,8]$. There are, however, no data on the relative potencies of the various inhaled corticosteroids in terms of their effects on bone or skin. The newer inhaled corticosteroids such as fluticasone and budesonide, which have more potent antiinflammatory activity than reference steroids such as dexamethasone, may also be more potent with respect to their unwanted effects on bone. 
The current study investigated the relative potencies of fluticasone, budesonide and its epimers (22R- and 22S-bu-desonide) and dexamethasone in several functional assays of human bone-derived osteoblast-like cells in vitro, using a well characterized model $[9,10]$.

\section{Methods}

Human bone-derived cells were prepared as described previously $[9,10]$. In brief, trabecular ends of long bones were obtained from several different donors of human foetal tissue between 17 and 20 weeks' gestation. The experimental protocol conformed to the guidelines of the National Health and Medical Research Council of Australia for the use of human foetal tissue and was approved by the Sydney University Medical Ethics Review Committee. The bones were dissected, scraped clean of adherent tissue and separated from their periosteum. The whole bone end was minced using scissors and washed extensively using primary growth medium before being plated out on to $25-\mathrm{cm}^{2}$ flasks (Nunc. Inter. Med., Roskilde, Copenhagen, Denmark) in BGJ medium (Fitton-Jackson Modification; Sigma Chemical Co., St. Louis, MO, USA) containing $10 \%(\mathrm{v} / \mathrm{v})$ foetal calf serum (FCS) and $44 \mathrm{mg}$. $\mathrm{mL}^{-1}$ phosphoascorbate, and supplemented with $30 \mu \mathrm{g}$. $\mathrm{mL}^{-1}$ penicillin and $40 \mu \mathrm{g} \cdot \mathrm{mL}^{-1}$ streptomycin (Commonwealth Serum Laboratories, Parkville, Australia). Cells grown from the explanted chips reached confluence after 3-4 weeks and were subcultured into 24-well plates (Becton-Dickinson, Rutherford, NJ, USA). Cells were plated at a concentration of $50,000-80,000$ cells $\cdot \mathrm{cm}^{-2}$, maintained in BGJ without antibiotics and supplemented with $10 \%$ (v/v) FCS overnight. The cells were maintained in this medium for the duration of the study with medium changes every $48 \mathrm{~h}$. Serum-containing medium was used for assays of $\left[{ }^{3} \mathrm{H}\right]$ thymidine incorporation and alkaline phosphatase activity due to poor development of osteoblasts and the high level of osteoblast apoptosis in serum-free medium $[11,12]$.

The stock solutions of fluticasone (GlaxoWellcome, Boronia, Victoria, Australia), budesonide and its epimers (Astra, Lund, Sweden) and dexamethasone (Sigma Chemical Co.) were added to spectroscopic grade ethanol so that the final concentration of vehicle did not exceed $0.1 \%$. In previous studies this concentration of ethanol had no effect on normal osteoblast-like cell function or proliferation. Dilutions of $10^{-7}-10^{-11} \mathrm{M}$ for all steroids were prepared. All steroid treatment commenced $24 \mathrm{~h}$ after subculture into 24-well plates and continued for the duration of the study as follows: 24 or $72 \mathrm{~h}$ for $\left[{ }^{3} \mathrm{H}\right]$ thymidine incorporation, 48 or $72 \mathrm{~h}$ for assay of alkaline phosphatase (AP) activity, $48 \mathrm{~h}$ for 1,25-dihydroxyvitamin $\mathrm{D}_{3}$ $\left(1,25(\mathrm{OH})_{2} \mathrm{D}_{3}\right)$-stimulated $\mathrm{AP}$ assay and 24 or $72 \mathrm{~h}$ for $1,25(\mathrm{OH})_{2} \mathrm{D}_{3}$-stimulated osteocalcin assay. The $1,25(\mathrm{OH})_{2}$ $\mathrm{D}_{3}$ (Roche, Sydney, Australia) was prepared in the same manner.

\section{Measurement of proliferation}

Cell numbers. The cells for counting from multiwell plates were harvested using $0.25 \%$ trypsin in Hank's buffered salt solution. The trypsinization was stopped by the addi- tion of a double volume of medium containing $10 \%$ FCS. Cell numbers were counted using a haemocytometer or Coulter counter.

$\left[{ }^{3} H\right]$ Thymidine incorporation. To quantify the incorporation of $\left[{ }^{3} \mathrm{H}\right]$ thymidine into deoxyribonucleic acid (DNA), human foetal bone-derived cells were incubated for $4 \mathrm{~h}$ at $37^{\circ} \mathrm{C}$ in a medium containing $37 \mathrm{kBq} \cdot \mathrm{mL}^{-1}\left(1 \mu \mathrm{Ci} \cdot \mathrm{mL}^{-1}\right)$ $\left[{ }^{3} \mathrm{H}\right]$ thymidine. At the end of the incubation, the monolayer was washed two or three times with ice-cold phosphate-buffered saline (PBS), followed by three 5-min rinses in ice-cold $10 \%$ trichloroacetic acid. The monolayer was then washed three times with ethanol at room temperature and allowed to dry before solubilization by incubation with $1 \mathrm{M} \mathrm{NaOH}$ with $1 \%$ Triton X-100 overnight at room temperature. The $800-\mu \mathrm{L}$ aliquots from the solubilized monolayer were added to $5 \mathrm{~mL}$ of scintillant liquid. $\left[{ }^{3} \mathrm{H}\right]$ Thymidine incorporation into DNA was measured using a $\beta$-counter [13].

\section{Measurement of differentiated functions}

Alkaline phosphatase assay. Alkaline phosphatase was measured in the culture wells using a modification of the LoWry [14] method with $p$-nitrophenol phosphate as a substrate. Media from cells were aspirated and the cell monolayer was washed three times at $37^{\circ} \mathrm{C}$ with PBS. One millilitre of reagent was added to each well at $10 \mathrm{~s}$ intervals [14]. The wells were incubated at $37^{\circ} \mathrm{C}$ for 30 min and the reaction was stopped by the addition of 800 $\mu \mathrm{L}$ of reagent/cell mixture to test tubes containing $1 \mathrm{~mL} 1$ $\mathrm{M} \mathrm{NaOH}$. Tubes were vortexed and the absorbance was measured at $405 \mathrm{~nm}$. Standard curves were prepared using serial dilutions of a $p$-nitrophenol solution. One unit of alkaline phosphatase hydrolyses $1 \mu \mathrm{mol} p$-nitrophenyl phosphate to $p$-nitrophenol and inorganic phosphate per minute at $37^{\circ} \mathrm{C}$ and $\mathrm{pH} 7.4$.

Assay of osteocalcin secretion. Measurements of osteocalcin in serum-free conditioned medium were made with a commercially available radioimmunoassay kit as described previously [15]. Since the corticosteroids have no detectable effect on osteocalcin secretion, measured by immunoassay, under basal conditions, their effect on osteocalcin secretion stimulated by $1,25(\mathrm{OH})_{2} \mathrm{D}_{3}\left(10^{-8} \mathrm{M}\right)$ was examined.

\section{Expression of results}

The median effective concentration (EC50) for each corticosteroid in each assay was obtained from a curve for each compound, which was derived by an iterative leastsquares nonlinear method (Sigma Plot 4.0, Jandel Scientific; SPSS Inc., Chicago, IL, USA) [16] using the following equation: $\mathrm{x}=[(\mathrm{ymax}-\mathrm{y} \min ) / 2]+\mathrm{ymin}$, where $\mathrm{x}=$ corticosteroid concentration $(\mathrm{nM})$ producing half maximal effective doses (EC50), ymax=maximum degree of response and ymin= minimum degree of response. From this single-fitted curve a single value for EC50 was obtained for each corticosteroid in that experiment.

The results were reported in two ways. 1) An average EC50 for the steroid in relation to any one of the functional end-points was calculated by taking a mean of the EC50 


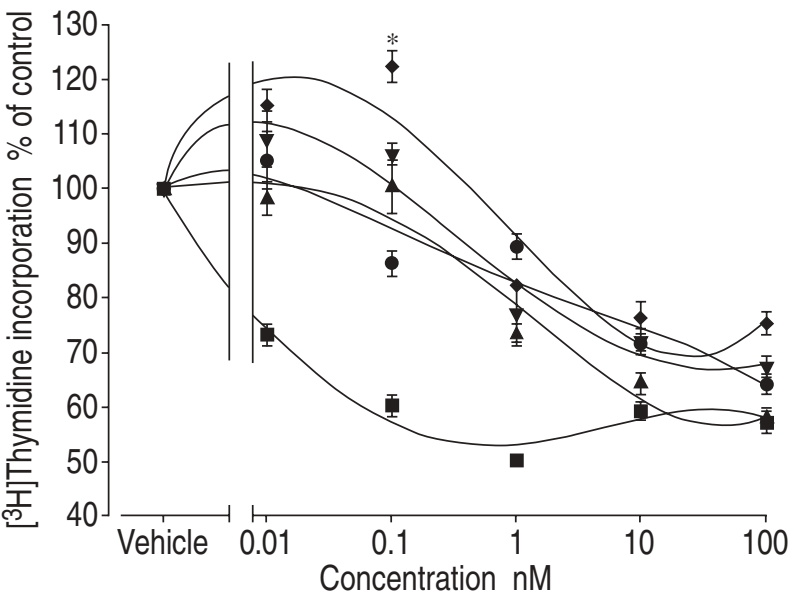

Fig. 1. - Effect of the corticosteroids, fluticasone (flut; - ), budesonide (bud; $\mathbf{\Delta})$, its epimers $(22 \mathrm{R}, \boldsymbol{\nabla} ; 22 \mathrm{~S}, \bullet)$ and dexamethasone (dex; $\bullet$ ) on $\left[{ }^{3} \mathrm{H}\right]$ Thymidine incorporation in human bone-derived osteoblast-like cells from FBC02046B. Results represent the mean \pm SEM of triplicate determinations. The following points were significantly different from vehicletreated cultures. *: p<0.05; p<0.01: dex $(0.1-100 \mathrm{nM}) ;$ bud, $22 \mathrm{R}$ and $22 \mathrm{~S}(1-100 \mathrm{nM})$; flut $(0.01-100 \mathrm{nM})$.

for each experiment. 2) The second method took into account the observation that cell strains from different donors varied in their responsiveness to corticosteroids and not all corticosteroids were tested with each cell strain. In this method, the EC50 for each corticosteroid was expressed as a ratio of the EC50 for dexamethasone for that experiment. This ratio indicated the relative potency of the steroid compared to that of dexamethasone for these cells from this donor. The average of these values for the particular corticosteroid was then calculated using values from individual assays and was termed the average potency.

Data were analysed for differences between groups by analysis of variance (ANOVA).

\section{Results}

Characteristics of human foetal bone-derived osteoblastlike cells

The explanted bone chips produced cells within $24 \mathrm{~h}$ of seeding. These cells, which reached confluence between 3 and 4 weeks after seeding, displayed osteoblast-like characteristics, such as increases in osteocalcin production and $\mathrm{AP}$ activity in response to $1,25(\mathrm{OH})_{2} \mathrm{D}_{3}$, and increases in cyclic adenosine monophosphate (cAMP) production after treatment with parathyroid hormone [9].

\section{Effects of corticosteroids on bone cell proliferation}

Treatment of human bone-derived cells with fluticasone, budesonide and its epimers (22R and $22 \mathrm{~S}$ ) resulted in a decrease in $\left[{ }^{3} \mathrm{H}\right]$ thymidine incorporation. This inhibition was comparable to that seen with dexamethasone (fig. 1). Treatment of cells with fluticasone resulted in a maximum decrease $(50 \pm 1 \%)$ at a concentration of $10^{-9} \mathrm{M}$ and less of an inhibitory response at higher doses of $10^{-8} \mathrm{M}$ and $10^{-7} \mathrm{M}$. A similar result was also seen in cells from a second donor. The average EC50 and average potencies for inhi-bition of $\left[{ }^{3} \mathrm{H}\right]$ thymidine incorporation are shown in table 1. Fluticasone had a consistently lower EC50 than bude-sonide or its epimers or dexamethasone. Over the whole dose-response range, there were no consistent differences between responses to budesonide or its epimers.

\section{Effects of corticosteroids on alkaline phosphatase activity}

Treatment of human bone-derived cells with corticosteroids over 48-72 h stimulated AP activity in a dosedependent manner (fig. 2). In all of the five experiments performed with fluticasone, the stimulatory effect of AP activity reached a maximum at concentrations of $10^{-9} \mathrm{M}$. At higher concentrations $\left(10^{-8} \mathrm{M}\right.$ and $\left.10^{-7} \mathrm{M}\right)$ stimulation was reduced compared with the peak stimulatory response. This bell-shaped dose-response curve remained after correction of AP activity for cell number. A bell-shaped dose-response curve for stimulation of AP was not observed with dexamethasone, budesonide or its epimers.

Even at maximal stimulatory doses of dexamethasone or budesonide, in the presence of $10^{-8} \mathrm{M} 1,25(\mathrm{OH})_{2} \mathrm{D}_{3}$, there was a further increase in AP activity. This was not the case at the maximal stimulatory dose of fluticasone $\left(10^{-9} \mathrm{M}\right)$ (fig. 3). The average EC50 and average potencies of corticosteroids for stimulation of AP activity are shown in table 2. In the two cell strains which were tested over the dose range $10^{-11}-10^{-7} \mathrm{M}$ with all five corticosteroids, the effects of fluticasone were significantly different from the other steroids $(\mathrm{p}<0.001)$ but there were no consistent significant differences between budesonide and its epimers.

\section{Effects of glucocorticoids on osteocalcin secretion}

Treatment of human bone-derived cells with vehicle, dexamethasone, budesonide and its epimers, or fluticasone alone did not result in any measurable osteocalcin secretion. The $1,25(\mathrm{OH})_{2} \mathrm{D}_{3}$-stimulated osteocalcin secretion

Table 1. - Median effective concentration ( $\mathrm{EC}_{50}$; $\mathrm{nM}$ ) and relative potencies of corticosteroids in the inhibition of [3H]thymidine incorporation in human bone-derived osteoblast-like cells

\begin{tabular}{|c|c|c|c|c|c|c|c|c|}
\hline \multirow{3}{*}{$\frac{\text { Cell strain }}{\text { FBC20105 }}$} & \multicolumn{8}{|c|}{$\mathrm{EC} 50 \mathrm{nM}$} \\
\hline & \multicolumn{2}{|c|}{ Flut } & $22 \mathrm{R}$ & \multicolumn{2}{|c|}{$22 \mathrm{~S}$} & \multicolumn{2}{|c|}{ Bud } & Dex \\
\hline & & & $0.27 \quad(4.8)$ & 0.4 & (3.3) & 0.5 & $(2.6)$ & $1.3(1)$ \\
\hline FBC13036B & 0.003 & $(67)$ & $0.1 \quad$ (2) & 0.45 & $(0.4)$ & 0.35 & $(0.57)$ & 0.2 (1) \\
\hline FBC02046B & 0.08 & (25) & $0.4 \quad(5)$ & 0.37 & (5.4) & 0.55 & $(3.6)$ & 2 (1) \\
\hline FBC03075 & 0.09 & (29) & & \multirow{2}{*}{\multicolumn{2}{|c|}{$0.4 \pm 0.02$}} & & & $2.6(1)$ \\
\hline EC50 mean \pm SEM & \multicolumn{2}{|c|}{$0.06 \pm 0.03$} & $0.26 \pm 0.08$ & & & \multicolumn{2}{|c|}{$0.47 \pm 0.06$} & $1.5 \pm 0.5$ \\
\hline Potency mean \pm SEM & \multicolumn{2}{|c|}{$40 \pm 13$} & $4 \pm 0.9$ & \multicolumn{2}{|c|}{$2.3 \pm 0.9$} & \multicolumn{2}{|c|}{$2.3 \pm 0.9$} & 1 \\
\hline
\end{tabular}

Values in parentheses indicate relative potency compared with dexamethasone (Dex). Flut: fluticasone; Bud: budesonide; 22R and 22S: epimers of Bud; FBC: foetal bone-derived cells. 


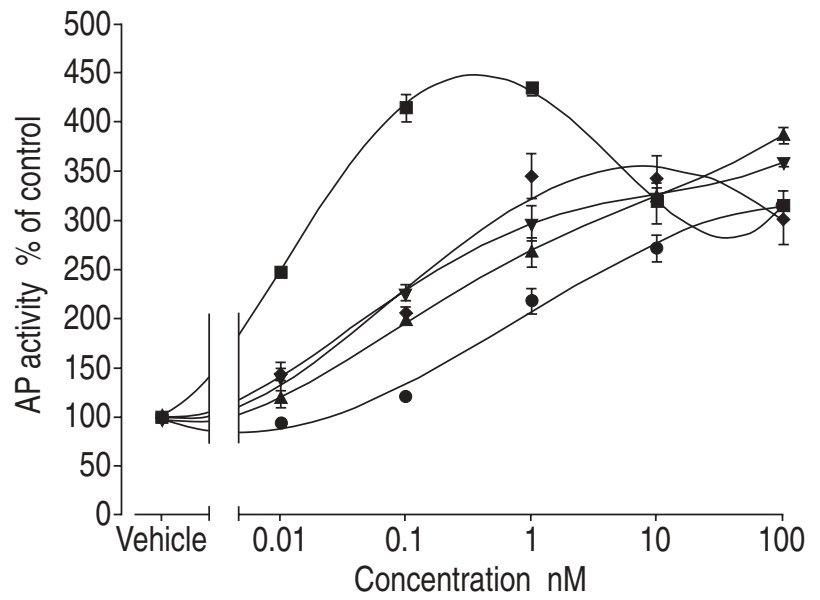

Fig. 2. - Effects of the corticosteroids, fluticasone (flut; $\mathbf{\square}$ ), budesonide (bud; $\mathbf{\Delta})$, its epimers $(22 \mathrm{R}, \mathbf{\nabla} ; 22 \mathrm{~S} ; \bullet)$ and dexamethasone (dex; $\bullet$ ) on alkaline phosphatase (AP) activity in FBC31071A cells. Results represent the mean \pm SEM of triplicate determinations. The following points were significantly different from vehicle-treated cultures: $\mathrm{p}<0.01$ : dex (0.1-100 nM); bud, 22R and 22S (0.01-100 nM); flut (0.01-100 nM).

was decreased in the presence of the corticosteroids (fig. 4). The average EC50 and the average potencies of the corticosteroids are shown in table 3. Again, fluticasone was significantly more potent than either dexamethasone or budesonide compounds, but there were no consistent significant differences between the responses to budesonide and its epimers.

\section{Discussion}

The results of this study showed that the human bonederived cell culture system revealed differences in the relative potencies between the commonly used inhaled corticosteroids. Qualitatively, the osteoblast-like cell responses to all of the corticosteroids were similar, with each corticosteroid causing dose-dependent inhibition of cell proliferation, stimulation of AP activity and inhibition of $1,25(\mathrm{OH})_{2} \mathrm{D}_{3}$-stimulated osteocalcin secretion. The changes in bone cell activities after corticosteroid treatment are similar to those reported by KASPERK et al. [17], who examined corticosteroids commonly administered systemically, for possible bone-sparing activity. Although formal EC50 were not calculated in that study, these authors showed that agents with less immunosuppressive activity, prednisolone and deflazacort, also had less activity in bone cells.

Overall comparison of average EC50 and average potencies of fluticasone, budesonide and its epimers, $22 \mathrm{R}$ and $22 \mathrm{~S}$, and dexamethasone are summarized in table 4. For all three parameters the rank order of potency was fluticasone $>22 \mathrm{R}=$ budesonide $=22 \mathrm{~S}>$ dexamethasone. These findings are similar to those seen in other assays, such as those measuring anti-inflammatory potency [18, 19], vasoconstriction (skin blanching) [20] or expression of secretory leukocyte protease inhibitor (SLPI), a prominent antiprotease produced by airway epithelial cells [16].

Fluticasone propionate has a high affinity and selectivity for the human glucocorticoid receptor compared with budesonide or dexamethasone, demonstrating a rapid receptor association and a slow receptor dissociation [21]. The calculated half-life of the fluticasone-receptor complex is $10 \mathrm{~h}$, exceeding that of budesonide $(5.1 \mathrm{~h})$, triamcinolone $(3.9 \mathrm{~h})$ and dexamethasone $(\sim 0.99 \mathrm{~h})$ [21]. Fluticasone is a highly lipophilic molecule with good uptake, binding and retention characteristics in human lung tissue [21,22]. The high topical activity of fluticasone and its few systemic side-effects are attributed to its structural fluorination and esterification [23].
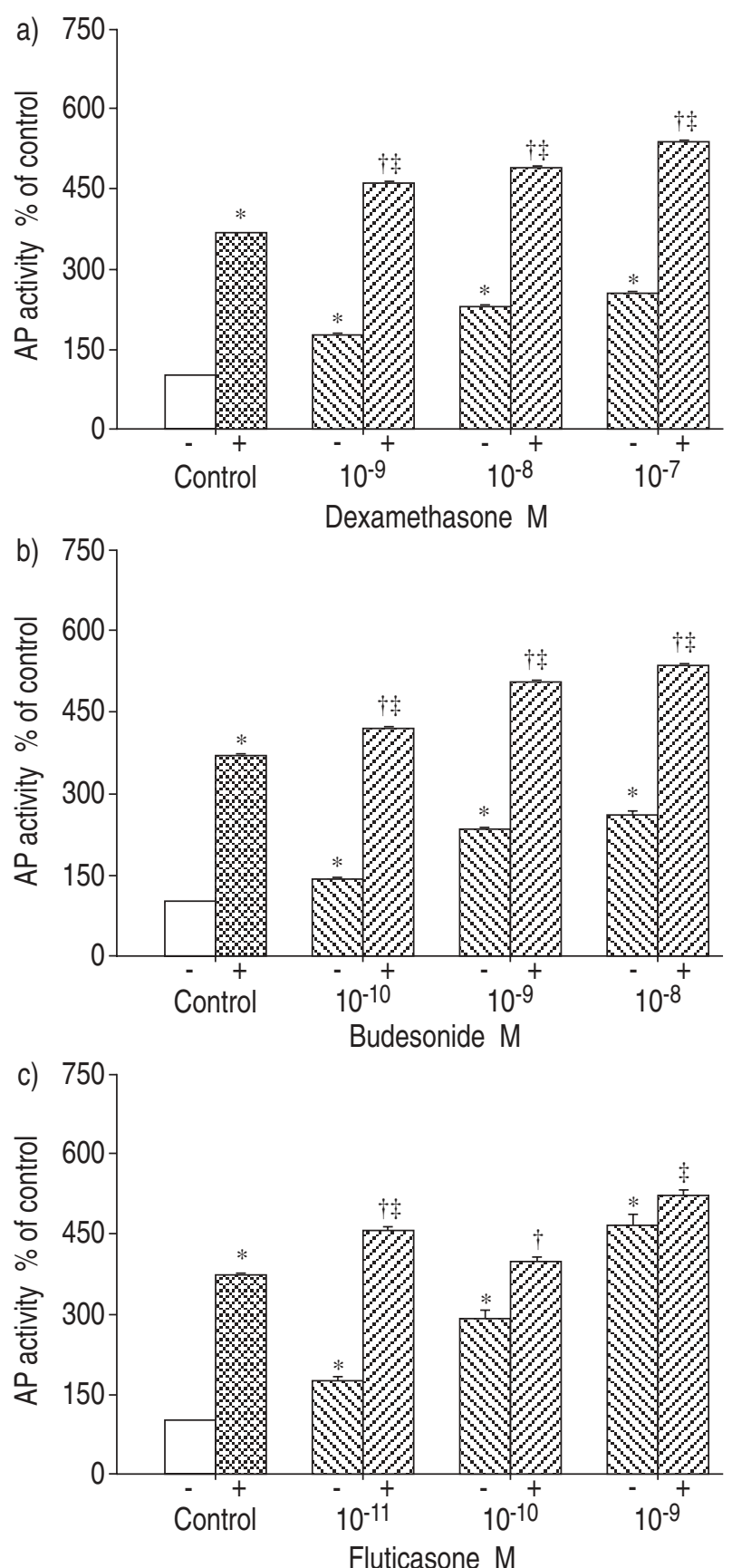

Fig. 3. - Effect of the corticosteroids, a) dexamethasone (dex), b) budesonide (bud) and c) fluticasone (flut) on 1,25-dihydroxyvitamin $\mathrm{D}_{3}$ $\left(1,25(\mathrm{OH})_{2} \mathrm{D}_{3}\right)$-stimulated alkaline phosphatase $(\mathrm{AP})$ activity. Cells were incubated in the presence $(+)$ or absence $(-)$ of $10^{-8} \mathrm{M} 1,25(\mathrm{OH})_{2} \mathrm{D}_{3}$. Results represent the mean \pm SEM of triplicate determinations. *: Significantly different from vehicle-treated control cultures, $\mathrm{p}<0.01$; $\uparrow$ : significantly different from corticosteroids alone, $\mathrm{p}<0.01$; : significantly different from $1,25(\mathrm{OH})_{2} \mathrm{D}_{3}$ alone, $\mathrm{p}<0.01$. 
Table 2. - Median effective concentration ( $\left.\mathrm{EC}_{50} ; \mathrm{nM}\right)$ and relative potencies of corticosteroids in the stimulation of alkaline phosphatase activity in human bone-derived osteoblast-like cells

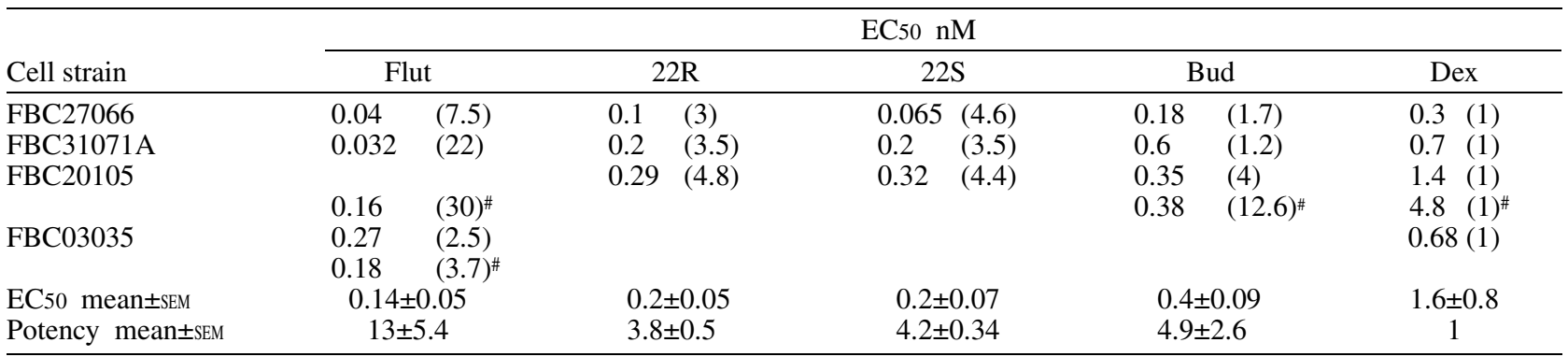

Values in parentheses indicate relative potency compared with dexamethasone (Dex). Flut: fluticasone; Bud: budesonide; 22R and 22S: epimers of Bud; FBC: foetal bone-derived cells. \#: second experiment with same cell stain.

In the current study budesonide exerted a greater overall potency than dexamethasone. These findings are in agreement with the results seen in other in vitro models derived from immune systems [24-26]. The more potent effect of budesonide compared with dexamethasone is also seen in their anti-inflammatory effects and clinical efficacy [20]. A higher potency of budesonide than dexamethasone in human bone-derived cells is also proposed to be associated with its slower receptor dissociation [21].

The potency of the two epimers of budesonide, 22R and $22 \mathrm{~S}$, have been compared by evaluating their anti-inflammatory effect [27]. In the human vasoconstriction test, $22 \mathrm{R}$ has been shown to have a two-fold increased topical anti-inflammatory potency compared with $22 \mathrm{~S}$ [27]. In vivo, the relative potencies of budesonide and its epimers, 22R and $22 \mathrm{~S}$, were $13,9.3$ and 8.2 compared with dexamethasone [1] in terms of their effect on the inhibition of rat ear oedema after topical administration. This rank order of potency among steroids is again consistent with their affinity for glucocorticoid receptors. Budesonide and its epimers, 22R and 22S, are bound to the same binding site as dexamethasone or triamcinolone $16 \alpha, 17 \alpha$-acetonide (TA), but with even higher affinity than dexamethasone or TA [28]. The affinity of $22 \mathrm{R}$ for the glucocorticoid recep-

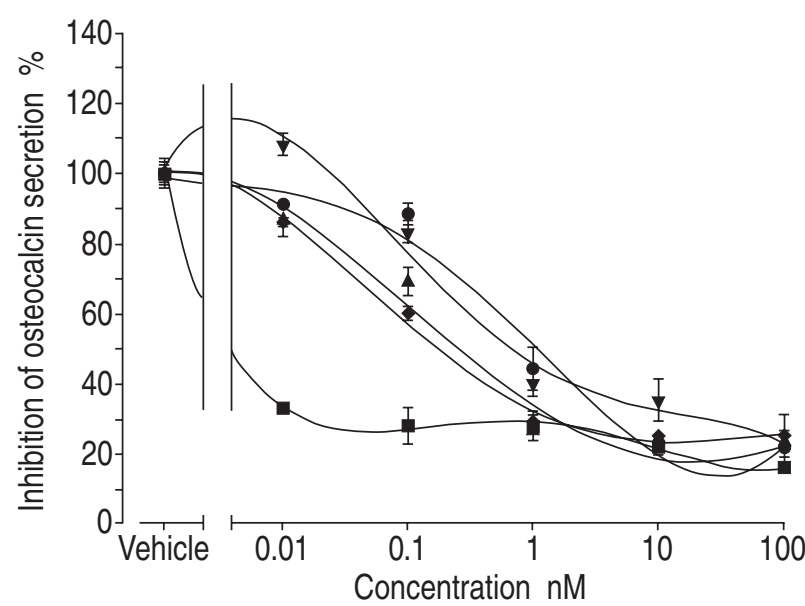

Fig. 4. - Effects of the corticosteroids, fluticasone (flut; $\mathbf{\square})$, budesonide (bud; $\mathbf{\Delta})$, its epimers $(22 \mathrm{R}, \boldsymbol{\nabla} ; 22 \mathrm{~S}, \bullet)$ and dexamethasone (dex; $\bullet$ ) on 1,25-dihydroxyvitamin $\mathrm{D}_{3}\left(1,25(\mathrm{OH})_{2} \mathrm{D}_{3}\right)$-stimulated osteocalcin production in the conditioned medium from human bone-derived cells. Results represent the mean \pm SEM of triplicate determinations. The following points were significantly different from $1,25(\mathrm{OH})_{2} \mathrm{D}_{3}$-stimulated osteocalcin production: $\mathrm{p}<0.01$ : dex $(0.01-100 \mathrm{nM})$; bud, $22 \mathrm{R}$ and $22 \mathrm{~S}(0.1-$ $100 \mathrm{nM})$; flut (0.001-100 nM). tor was twice as high as that of $22 \mathrm{~S}$, four times higher than TA and 14 times higher than dexamethasone [28]. The observed inconsistencies in the relative potencies of $22 \mathrm{R}$ and $22 \mathrm{~S}$ on the parameters tested in human bone-derived cells may be the result of as yet unknown differences in the donors tested for each parameter. The fixed doseresponse range and the limited number of donors may have impeded the demonstration of consistent, relatively small differences in potencies between the budesonide compounds.

The bell-shaped dose-response curve of AP activity in response to fluticasone remained even after correction of AP activity for cell number, indicating that this effect was not caused by a decrease in cell number due to fluticasone. Similar biphasic effects of glucocorticoids have also been reported by QuiRK et al. [29]. The highly selective type II glucocorticoid ligand RU28362 showed a clear biphasic effect on $\alpha$-lactalbumin production when mouse mammary explants are cultured in the presence of insulin and prolactin, with a peak at $1 \mathrm{nM}$ and a return to basal levels at 30-300 nM [29]. Dexamethasone and corticosterone also had a similar biphasic effect in some experiments in that study. A similar biphasic response to dexamethasone was observed for aromatase activity in fibroblasts [30]. In cultured hepatoma cells, continued exposure to dexamethasone increased glucocorticoid receptor messenger ribonucleic acid (mRNA) initially, followed by inhibition and a subsequent return to control levels [31].

It has been suggested that this pattern may be the result of the existence of both "turn-on" and "turn-off" acceptor sites in the promotor region of the gene [29]. Therefore, if a particular glucocorticoid system is responsive to two (or more) glucocorticoid regulatory elements (GRE), one turn-on and one turn-off, a bell-shaped dose-response curve can be generated.

There has been increasing evidence of adverse effects of inhaled corticosteroids on parameters related to bone formation, such as serum osteocalcin [32] and procollagen concentrations [33], as well as on concentrations of sex steroids, such as androgens [34], in asthmatic subjects. Bone resorption-related parameters have been reported to be increased [35], unchanged [34, 36] or decreased [5]. A decrease in bone density has also been observed in asthmatic subjects treated with inhaled corticosteroids [37].

In vivo, several factors may influence systemic endorgan activity, including the absorption, distribution, biotransformation and excretion of a drug. Potency is also determined by the compound's inherent ability to combine 
Table 3. - Median effective concentration ( $\mathrm{EC}_{50}$; $\left.\mathrm{nM}\right)$ and relative potencies of corticosteroids in the inhibition of 1,25dihydroxyvitamin $\mathrm{D}_{3}$-stimulated osteocalcin secretion by human bone-derived osteoblast-like cells

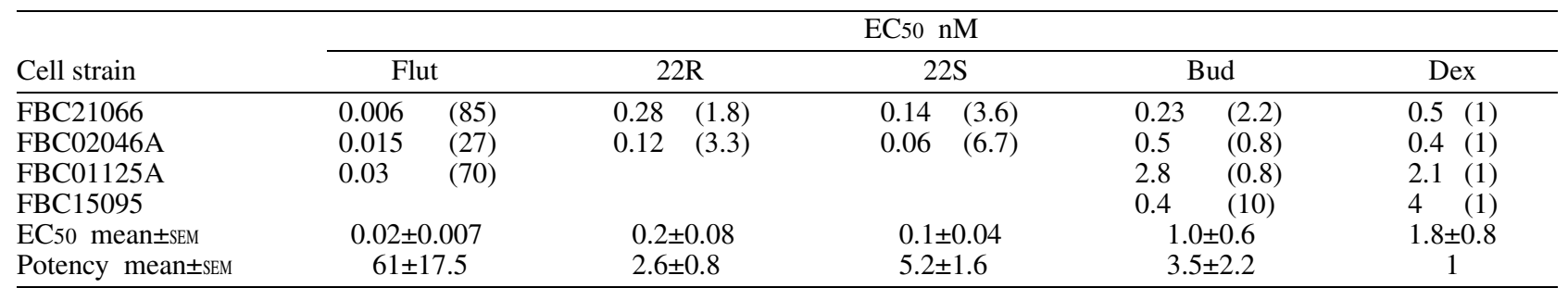

Values in parentheses indicate relative potency compared with dexamethasone (Dex). Flut: fluticasone; Bud: budesonide; 22R and 22S: epimers of Bud; FBC: foetal bone-derived cells.

with its receptors and the functional relationship between the receptor and the effector system [38]. Fluorination of a drug [27], lipophilicity and structural variation via esterification also enhance the potency of topical steroids. The relative importance of these factors has, however, not yet been fully evaluated.

The histomorphometric picture of corticosteroid-induced osteoporosis is characterized primarily by impaired osteoblastic activity, exacerbated by enhanced activation frequency of bone remodelling units [39]. Impaired osteoblastic activity may be the result of reduced numbers of mature osteoblasts or decreased function of each mature bone cell. The results shown here and by others [17] are consistent with the proposal that corticosteroids, by inducing early termination of cell proliferation in vitro and presumably in vivo, favour the differentiation of osteoblasts, resulting in smaller numbers of more mature cells. These highly mature cells would display high AP activity. The net effect of corticosteroids is a reduction in the total number of cells which are capable of bone replacement. Thus, the relative potencies of the inhaled corticosteroids in terms of their antiproliferative activity in human bonederived osteoblast-like cells may be the most relevant with respect to their unwanted systemic effects on bone in vivo. Other possible mechanisms contributing to reduced numbers of mature osteoblasts for bone replacement in the presence of pharmacological concentrations of corticosteroids include a corticosteroid-induced increase in osteoblast apoptosis [40, 41] and a tendency for mesenchymal progenitors to differentiate along an adipocytic rather than osteoblastic lineage under some conditions in the pres-

Table 4. - Overall comparison of mean median effective concentrations (EC50) and relative potencies of corticosteroids in human bone-derived osteoblast-like cells

\begin{tabular}{|c|c|c|c|c|c|c|}
\hline \multirow[t]{2}{*}{ Corticosteroids } & \multicolumn{2}{|c|}{$\begin{array}{l}\text { Inhibition of } \\
{[3 \mathrm{H}] \text { thymidine }} \\
\text { incorporation }\end{array}$} & \multicolumn{2}{|c|}{$\begin{array}{c}\text { Stimulation of } \\
\text { alkaline } \\
\text { phosphatase } \\
\text { activity }\end{array}$} & \multicolumn{2}{|c|}{$\begin{array}{l}\text { Inhibition of } \\
\text { osteocalcin } \\
\text { secretion* }\end{array}$} \\
\hline & $\begin{array}{c}\text { EC50 } \\
\text { nM }\end{array}$ & $\begin{array}{l}\text { Relative } \\
\text { potency }\end{array}$ & $\begin{array}{c}\text { EC50 } \\
\mathrm{nM}\end{array}$ & $\begin{array}{l}\text { Relative } \\
\text { potency }\end{array}$ & $\begin{array}{c}\text { EC50 } \\
\mathrm{nM}\end{array}$ & $\begin{array}{l}\text { Relative } \\
\text { potency }\end{array}$ \\
\hline Flut & 0.06 & 40 & 0.14 & 13 & 0.02 & 61 \\
\hline $22 \mathrm{R}$ & 0.26 & 4 & 0.2 & 3.8 & 0.2 & 2.6 \\
\hline $22 \mathrm{~S}$ & 0.4 & 3 & 0.2 & 4.2 & 0.1 & 5.2 \\
\hline Bud & 0.47 & 2.3 & 0.4 & 4.9 & 1.0 & 3.5 \\
\hline Dex & 1.5 & 1 & 1.6 & 1 & 1.8 & 1 \\
\hline
\end{tabular}

Values are presented as means. Relative potencies are compared with dexamethasone (Dex). *: inhibition of 1,25-dihydroxyvitamin $\mathrm{D}_{3}$-stimulated osteocalcin secretion; Flut: fluticasone; Bud: budesonide; 22R and 22S: epimers of Bud. ence of corticosteroids [42]. The reduction in osteocalcin secretion per cell indicates that at least some functions of mature cells are also reduced by corticosteroids. It was recently reported that osteocalcin-deficient mice had a gre-ater nonmaturing mineral content across the bone cortices than that in wild-type mice [43]. A corticosteroid-induced reduction in osteocalcin secretion may contribute to im-paired mineral maturation [43] and, thus, to increased risk of fractures.

The current study provides evidence that in bone cells, the trend of relative potencies of the steroids in producing these potentially adverse effects seems to be similar to the results derived from immune cell models [44].

Acknowledgements: The authors thank R. Brattsand and S. Edsbacker, Astra Draco, for providing budesonide and its epimers and Glaxo Wellcome for fluticasone propionate.

\section{References}

1. Geddes DM. Inhaled corticosteroids: benefits and risks. Thorax 1992; 47: 404-407.

2. Cumming RG, Mitchell P, Leeder SR. Use of inhaled corticosteroids and the risk of cataracts. N Engl J Med 1997; 337: 8-14.

3. Capewell S, Reynolds S, Shuttleworth D. Purpura and dermal thinning associated with high dose inhaled corticosteroids. BMJ 1991; 300: 1548-1549.

4. Boulet LP, Giguere MC, Milot J, Brown J. Effects of long-term use of high-dose inhaled steroids on bone density and calcium metabolism. J Allergy Clin Immunol 1994; 94: 796-803.

5. Birkebaek NH, Esberg G, Andersen K, Wolthers O, Hassager $\mathrm{C}$. Bone and collagen turnover during treatment with inhaled dry powder budesonide and beclomethasone dipropionate. Arch Dis Child 1995; 73: 524-527.

6. Grove A, Allam C, McFarlane LC, McPhate G, Jackson CM, Lipworth BJ. A comparison of the systemic bioactivity of inhaled budesonide and fluticasone propionate in normal subjects. Br J Clin Pharmacol 1994; 38: 527-532.

7. Toogood JH, Crilly RG, Jones G, Nadeau J, Wells GA. Effect of high-dose inhaled budesonide on calcium and phosphate metabolism and the risk of osteoporosis. Am Rev Respir Dis 1988; 138: 57-61.

8. Leech JA, Hodder RV, Ooi DS, Gay J. Effects of shortterm inhaled budesonide and beclomethasone dipropionate on serum osteocalcin in premenopausal women. $A m$ Rev Respir Dis 1993; 148: 113-115.

9. Slater M, Patava J, Kingham K, Mason RS. Modulation of growth factor incorporation into ECM of human osteoblast-like cells in vitro by 17 beta-estradiol. Am J Physiol 1994; 267: E990-E1001. 
10. Slater M, Patava J, Mason RS. Role of chondroitin sulfate glycosaminoglycans in mineralizing osteoblast-like cells: effects of hormonal manipulation. J Bone Miner Res 1994; 9: 161-169.

11. Tenenbaum HC, Heersche JNM. Dexamethasone stimulates osteogenesis in chick periosteum in vitro. Endocrinology 1985; 117: 2211-2217.

12. Kitajima I, Takasaki I, Maruyama I. Role of apoptosis and tumour necrosis factor- $\alpha$-generated ceramide in murine clonal osteoblasts. J Bone Miner Res 1996; 11: Suppl. $1, \mathrm{~S} 166$.

13. Stubblefield E, Klevecz R, Deaven L. Synchronised mammalian cell cultures. J Cell Physiol 1967; 69: 345-353.

14. Lowry OH. Specific procedures. Alkaline phosphatase. In: Pastan IH, ed. Micromethods for the Assay of Enzymes. New York, Academic Press, 1995; pp. 265-371.

15. Wilkinson MR, Wagstaffe C, Delbridge L, Wiseman J, Posen S. Serum osteocalcin concentrations in Paget's disease of bone. Arch Intern Med 1986; 146: 268-271.

16. Abbinante-Nissen JM, Simpson LG, Leikauf GD. Corticosteroids increase secretory leukocyte protease inhibitor transcript levels in airway epithelial cells. Am J Physiol 1995; 268: L601-L606.

17. Kasperk C, Schneider U, Sommer U, Niethard F, Ziegler R. Differential effects of glucocorticoids on human osteoblastic cell metabolism in vitro. Calcif Tissue Int 1995; 57: $120-126$.

18. Chung KF, Wiggins J, Collins J. Bronchial asthma. In: Weiss EB, Stein M, eds. Mechanisms and Therapeutics. Boston, MA, Little Brown, 1993; pp. 800-817.

19. Roca-Ferrer J, Mullol J, Lopez E, et al. Effect of topical anti-inflammatory drugs on epithelial cell-induced eosinophil survival and GM-CSF secretion. Eur Respir $J$ 1997; 10: 1489-1495.

20. Barnes PJ, Pedersen S. Efficacy and safety of inhaled corticosteroids in asthma. Am Rev Respir Dis 1993; 148: S1.

21. Hogger P, Rohdewald P. Binding kinetics of fluticasone propionate to the human glucocorticoid receptor. Steroids 1994; 59: 597-602.

22. Fuller R, Johnson M, Bye A. Fluticasone propionate: an update on preclinical and clinical experience. Respir Med 1995; 89: 3-18.

23. Piacquadio DJ. Topical corticosteroids in clinical practice: focus on fluticasone propionate. Cutis 1996; 57: 4-9.

24. Bergstrand H, Björnson A, Lundquist B, Nilsson A, Brattsand R. Inhibitory effect of glucocorticoids on antiIgE-induced histamine release from human basophilic leukocytes: evidence for a dual mechanism of action. Allergy 1984; 39: 217-230.

25. Schmidt J, Fleissner S, Heimann-Weitschat I, Lindstaedt $\mathrm{R}$, Szelenyi I. The effect of different corticosteroids and cyclosporin A on interleukin-4 and interleukin-5 release from murine TH2-type T cells. Eur J Pharmacol 1994; 260: 247-250.

26. Oddera S, Silvestri M, Sacco O, Lantero S, Morelli MC, Rossi GA. Evaluation of the inhibitory effects of budesonide on the mitogen-induced or the allergen-induced activation of blood mononuclear cells isolated from asthmatic patients. Ann Allergy Asthma Immunol 1995; 75: 33-40.

27. Brattsand R, Thalén A, Roempke K, Källström L, Gruvstad E. Influence of steroid nucleus fluorination and type of $16 \alpha, 17 \alpha$-acetal substitution on the topical to systemic glucocorticoid activity ratio of $16 \alpha, 17 \alpha$-acetal corticoids. J Steroid Biochem 1982; 16: 779-786.

28. Dahlberg E, Thalen A, Brattsand R, et al. Correlation between chemical structure, receptor binding, and biolog- ical activity of some novel, highly active, 16 alpha, 17 alpha-acetal-substituted glucocorticoids. Mol Pharmacol 1983; 25: 70-78.

29. Quirk SJ, Gannell JE, Fullerton MJ, Funder JW. Mechanisms of biphasic action of glucocorticoids on alpha-lactalbumin production by rat mammary gland explants. $J$ Steroid Biochem 1986; 24: 413-416.

30. Fujimoto M, Berkovitz GD, Brown TR, Migeon CJ. Timedependent biphasic response of aromatase to dexamethasone in cultured human skin fibroblasts. J Clin Endocrinol Metab 1986; 63: 468-474.

31. Orket S, Poellinger L, Dong Y, Gustafsson JA. Down-regulation of glucocorticoid receptor mRNA by glucocorticoid hormones and recognition by the receptor of a specific binding sequence within a receptor cDNA clone. Proc Natl Acad Sci USA 1986; 83: 5899-5903.

32. Meeran K, Hattersley A, Burrin J, Shiner R, Ibbertson K. Oral and inhaled corticosteroids reduce bone formation as shown by plasma osteocalcin levels. Am J Respir Crit Care Med 1995; 151: 333-336.

33. Puolijoki H, Risteli J, Herrala J, Risteli L, Lippo K. Effects of inhaled beclomethasone on serum markers of collagen metabolism in postmenopausal asthmatic women. Respir Med 1996; 90: 339-342.

34. Jennings BH, Andersson KE, Johansson SA. Assessment of systemic effects of inhaled glucocorticosteroids: comparison of the effects of inhaled budesonide and oral prednisolone on adrenal function and markers of bone turnover. Eur J Clin Pharmacol 1991; 40: 77-82.

35. Ali NJ, Capewell S, Ward MJ. Bone turnover during high dose inhaled corticosteroid treatment. Thorax 1991; 46: 160-164.

36. Bootsma GP, Dekhuijzen PN, Festen J, Mulder PG, Swinkels LM, Van Herwaarden CL. Fluticasone propionate does not influence bone metabolism in contrast to beclomethasone dipropionate. Am J Respir Crit Care Med 1996; 153: 924-930.

37. Hanania NA, Chapman KR, Sturtridge WC, Szalai JP, Kesten S. Dose-related decrease in bone density among asthmatic patients treated with inhaled corticosteroids. $J$ Allergy Clin Immunol 1995; 96: 571-579.

38. Andersson P, Edsbacker S, Ryrfeldt A, von Bahr C. In vitro biotransformation of glucocorticoids in liver and skin homogenate fraction from man, rat and hairless mouse. $J$ Steroid Biochem 1982; 16: 787-795.

39. Dempster DW. Bone histomorphometry in glucocorticoidinduced osteoporosis. J Bone Miner Res 1989; 4: 137-141.

40. Chiu KM, Crenshaw T, Gravenstein S. Is the age-related decline in bone formation due to reduced osteoblast number? J Bone Miner Res 1996; 11: Suppl. 1, S391.

41. Gohel A, Gronowicz G. Glucocorticoids induce apoptosis in osteoblasts by the regulation of Bcl-2, Bax and other cell cycle factors. J Bone Miner Res 1997; 12: Suppl. 1, S284.

42. Nuttall ME, Patton AJ, Olivera DL, Nadeau DP, Gowen M. Human trabecular bone cells are able to express both osteoblastic and adipocytic phenotype: implications for osteopenic disorders. J Bone Miner Res 1998; 13: 371382.

43. Boskey AL, Gadaleta S, Gunberg C, Ducy P, Karsenty G. Fourier transform infrared microscopy (FTIRM) provides clues to the in situ function of osteocalcin. J Bone Miner Res 1997; 12: Suppl. 1, S146.

44. English AF, Neate MS, Quint DJ, Sareen M. Biological activities of some steroids used in asthma. Am J Respir Crit Care Med 1994; 149: A4. 